JURNAL PENDIDIKAN, p-ISSN 2715-095X, e-ISSN 2686-5041

Volume 30, No.2, Juli 2021 (299-310)

Online: http://journal.univetbantara.ac.id/index.php/jp

\title{
Penerapan Model Pembelajaran Number Heads Together untuk Meningkatkan Prestasi Belajar IPA Materi Perubahan Benda Siswa Kelas VI SDN Cemani 03 Tahun Pelajaran 2019/2020
}

\author{
Haryanti
}

SDN Cemani 03, Grogol Sukoharjo, Kabupaten Sukoharjo, E-mail: haryanti1101@gmail.com

Received: May 27, 2021

Accepted: Juni 07, 2021

Online Published: Juni 26, 2021

\begin{abstract}
Abstrak: Latar belakang diadakan penelitian tindakan kelas ini adalah data nilai rata rata ulangan harian sebesar 67. Rendahnya nilai rata-rata kelas disebabkan oleh siswa kurang antusias mengikuti pelajaran IPA dikarenakan kurang tepatnya metode, model ataupun strategi yang digunakan guru dalam mengajar IPA. Rumusan masalah dalam penelitian ini adalah apakah pembelajaran dengan menggunakan Model Numbered Heads Together (NHT) dapat meningkatkan prestasi belajar siswa pada materi perubahan benda pada siswa kelas VI SD siswa kelas VI SD Negeri Cemani 03 Sukoharjo semester 1 tahun pelajaran 2019/2020. Waktu penelitian selama 5 bulan mulai bulan Agustus 2019 sampai Desember 2019. Subjek penelitian adalah seluruh siswa kelas VI yang berjumlah 29 siswa Sekolah SD Negeri Cemani 03 Sukoharjo semester 1 tahun pelajaran 2019/2020, sedangkan yang menjadi objek penelitian yaitu kegiatan belajar dalam rangka meningkatkan prestasi belajar IPA perubahan benda siswa kelas VI Sekolah SD Negeri Cemani 03 Kabupaten Sukoharjo melalui penerapan model pembelajaran NHT. Pada pelaksanaan PTK ini, peneliti akan menggunakan tiga teknik dalam pengumpulan data. Ketiga teknik tersebut diharapkan bisa dikolaborasikan sehingga mendapatkan hasil sesuai dengan yang diharapkan. Hasil penelitian menunjukkan bahwa melalui penerapan model pembelajaran NHT di duga dapat meningkatkan hasil belajar IPA materi perubahan benda siswa kelas VI SD Negeri Cemani 03 Sukoharjo semester 1 tahun pelajaran 2019/2020terbukti kebenarannya. Peningkatan ketuntasan belajar siswadari 59\% pada kondisi awal meningkat menjadi $76 \%$ pada siklus I dan meningkat menjadi $100 \%$ pada siklus II. Peningkatan nilai rata-rata ulangan harian dan ketuntasan belajar peningkatan kriteria ketuntasan secara klasikal jugasudah tercapai.
\end{abstract}

Kata-kata Kunci: NHT, prestasi belajar, perubahan benda.

\section{Application of the Number Heads Together Learning Model to Improve Science Learning Achievement in Material Change of Class VI Students at SDN Cemani 03 Academic Year 2019/2020}

\section{Haryanti}

SDN Cemani 03, Grogol Sukoharjo,Sukoharjo Regency,E-mail:haryanti1101@gmail.com

\begin{abstract}
The background of this classroom action research is the data on the mean value of daily tests of 67. The low class average score is caused by students who are less enthusiastic about taking science lessons due to the lack of precise methods, models or strategies used by the teacher in teaching science. is whether learning using the NHT (Numbered heads Together) Model can improve student learning achievement in material changing objects in class VI SD students of SD Negeri Cemani 03 Sukoharjo Semester 1 in the 2019/2020 academic year. The research time was 5 months from August 2019 to December 2019. The research subjects were
\end{abstract}


all students in grade VI, totaling 29 students of SD Negeri Cemani 03 Sukoharjo Semester 1 in the 2019/2020 academic year, while the object of research was learning activities to improve achievement learning science object change in class VI SD Negeri Cemani 03 Sukoharjo regency through the application of the NHT learning model. In the implementation of this Classroom Action Research, researchers will use three techniques in data collection. When these techniques are expected to be collaborated so as to get the results as expected. The results showed that "Through the application of the NHT learning model, it is assumed that the learning outcomes of science learning material change in object change material for class VI SD Negeri Cemani 03 Sukoharjo semester 1 of the 2019/2020 academic year" proved to be true "The increase in student learning completeness from $59 \%$ in the initial conditions increased to $76 \%$ in cycle I and increased to $100 \%$ in cycle II. The increase in the average value of daily tests and mastery learning has also been achieved

Keywords: NHT, learning achievement change of objects

\section{Pendahuluan}

Pada Sekolah Dasar kelas VI pembelajaran IPA salah satu materinya memuat tentang Perubahan Benda. Melalui materi pokok ini siswa diharapkan mampu memahami dan menjelaskan beberapa faktor yang mempengaruhi perubahan benda, misalnya pelapukan, perkaratan, pembusukan dan lainnya. Dalam materi ini siswa juga diwajibkan untuk tahu dan mengerti penyebab dan cara penanggulangannya. Model pembelajaran IPA yang dilakukan bagi siswa kelas VI SD Negeri Cemani 03 adalah model ceramah. Materi yang disampaikan oleh guru di depan kelas dan siswa mendengarkan serta mencatat hal yang penting. Menurut pengamatan dari guru selama ini model pembelajaran itu masih bisa diterima oleh siswa. Ketika pembelajaran berlangsung, hampir semua siswa memperhatikan dan mencatat apa yang disampaikan oleh guru, hal ini menjadikan perasaan cukup puas bagi guru. Selang beberapa hari kemudian, peneliti melakukan evaluasi untuk menilai seberapa besar pemahaman dan penguasaan terhadap materi yang telah diajarkan (Suwarto, 2009). Ternyata hasil yang diperoleh siswa sangat memprihatinkan karena dari 29 siswa kelas VI hanya 17 (tujuh belas) siswa yang mencapai tingkat penguasaan materi $80 \%$ keatas.

Salah satu usaha yang dilakukan siswa adalah membuat catatan. Mereka mencatat materi pelajaran tetapi kenyataannya mereka tidak dapat menyerap materi dengan baik. Dengan demikian, diperlukan metode yang sesuai, sebagai alternatif dari pemecahan masalah tersebut. Guru harus mampu dan kreatif untuk memvariasi model pembelajaran sehingga di dapat hasil belajar yang optimal. Peneliti mengamati dari data nilai harian kelas VI semester 1 di dapat nilai rata-rata 67, terlihat jelas bahwa nilai rata-rata siswa masih berada di bawah nilai ketuntasan belajar yang ditetapkan yaitu 70 . Rendahnya nilai rata-rata kelas disebabkan oleh siswa kurang antusias mengikuti pelajaran IPA dikarenakan kurang tepatnya metode, model ataupun strategi yang digunakan guru dalam mengajar IPA. Oleh sebab itu peneliti mencoba alternative pembelajaran Numbered Heads Together disingkat NHT. Pembelajaran ini didominasi oleh siswa, dengan mengedepankan diskusi tanya jawab antar siswa sehingga siswa lebih kreatif dan juga berani untuk mengemukakan keberaniannya.

Pembelajaran adalah proses, cara, menjadikan orang atau makhluk hidup belajar. Sedangkan belajar adalah berusaha memperoleh kepandaian atau ilmu, berubah tingkah laku atau tanggapan yang disebabkan oleh pengalaman. (KBBI, 2008: 17). Secara garis besar pembelajaran dapat diartikan sebagai sebuah proses yang disengaja untuk mencapai 
suatu hal, antara lain perubahan tingkah laku, bertambahnya keahlian dan meningkatkan kualitas seseorangPembelajaran Ilmu Pengetahuan Alam khususnya di Sekolah Dasar merupakan acuan siswa untuk mempelajarai segala hal yang berkaitan dengan sains.

Menurut Maslichah Asy'ari (2006: 7), Ilmu Pengetahuan Alam atau sains didefinisikan sebagaipengetahuan manusia tentang alam yang diperoleh dengan caraterkontrol. Maslichah Asy'ari (2006: 7) mengemukakan hakikat Ilmu Pengetahuan Alam atau sains terdapat tiga dimensi, yaitu sains sebagai ilmu, sains sebagai proses, \& sains menjadi produk. Maslichah Asy'ari (2006: 8) menyatakan bahwa keberadaan dan perkembangan ilmu wajib diusahakan menggunakan adanya aktivitas manusia serta kegiatan wajib dilakukan menggunakan menggunakan metode tertentu yang akhirnya aktivitas metodis tadi akan membuat pengetahuan yang sistematis.Menurut penelitian Desak Ketut Paramita (2016) menjelaskan bahwa pembelajaran IPA mempunyai bagian penting dalam peningkatan kualitas pendidikan, khususnya dalam menghasilkan siswa yang berkualitas, yaitu manusia yang berpikir kritis, kreatif, logis dan berinisiatif dalam menanggapi isu di masyarakat. Djojosoediro (2010:3) menjelaskan mengenai IPA sebagai ilmu pengetahuan yang memepelajari gejala alam yang melingkupi fakta, konsep, prinsip dan hukum yang teruji kebenarannya dan melalui suatu rangkaian kegiatan dalam metode ilmiah. Metode ilmiah berupa pengamatan dan eksperimen serta menuntut sikap ilmiah seperti rasa ingin tahu, terbuka, jujur, dan sebagainya. Apabila rasa ingin tahu siswa tentang objek dan fenomena alam tersebut terwujud, maka tujuan pembelajaran IPA yang diajarkan di tingkat Sekolah Dasar (SD) akan terwujud.

Pembelajaran IPA di SD diharapkan dapat menjadi saran untuk peserta didik untuk mempelajari diri sendiri dan alam sekitarnya, serta proses akan dikembangkan lebih dalam kehidupan sehari-hari, yang dapat membantu siswa untuk memperoleh pemahaman yang lebih lanjut. Pada kenyataan yang ada di lapangan masih banyak ditemui data hasil belajar IPA siswa yang masih rendah (Suprapti Hariyani, 2019). Susanto (2014) menyebutkan bahwa dalam proses kegiatan belajar mengajar di kelas yang ditujukan pada peningkatan kemampuan pemahaman siswa dalam menghafal informasi, otak siswa dipaksa hanya mengingat dan menyimpan informasi tanpa harus memahami dan mengolah informasi yang diperoleh yang akan diterapkannya dalam kehidupan sehari hari.Dengan pengertian tersebut makam sains mencakup tiga aspek yaitu aspek aktivitas, aspek metode, dan aspek pengetahuan. Sebagai suatu proses, sains merupakan cara kerja, cara berfikir dan cara memecahkan suatu masalah. Cara kerja ilmu pengetahuan alam tersebut disebut dengan istilah metode ilmiah. Untuk anak sekolah dasar, metode ilmiah dikembangkan secara bertahap dan berkelanjutan dengan harapan pada akhirnya akan terbentuk kombinasi yang lebih lengkap sehingga anak sekolah dasar dapat melaksanakan penelitian sederhana.

Pada intinya dalam proses memperoleh Ilmu Pengetahuan Alam dibutuhkan keterampilan dasar, Oleh karena itu, diperlukan jenis keterampilan dasar dalam prosesnya untul mendapatkan Ilmu Pengetahuan Alam disebut juga "keterampilan proses". Maslichah Asy'ari (2006:9) menjelaskan bahwa produk sains merupakan kumpulan pengetahuan yang tersusun dalam bentuk fakta, konsep, prinsip, hukum, dan teori. Fakta merupakan produk sains yang paling dasar. Realitas diperoleh dari konsekuensi persepsi secara serius dan terus menerus atau konsisten. Ilustrasi dari item logis yang menjadi kenyataan adalah gula, rasanya manis, logam tenggelam dalam air. Ide-ide dalam sains dikomunikasikan sebagai pertimbangan tentang artikel atau acara khas. Kadang-kadang gagasan itu diuraikan sebagai definisi atau klarifikasi. Contoh permasalahan logis yang merupakan gagasan adalah: (1) Gas adalah zat dan volume yang bentuknya dapat berubah. (2) Satelit adalah benda langit 
yang bergerak di seluruh dunia. (3) Air adalah zat yang partikelnya tersusun dari 2 molekul hidrogen iota dan 1 molekul oksigen. Standar adalah spekulasi tentang keterkaitan antara gagasan yang terkait (Maslichah Asy'ari, 2006: 10). Aturan tersebut di dapat melalui interaksi penerimaan dari berbagai jenis persepsi.

Dari beberapa tinjauan teori di atas maka dapat disimpulkan bahwa pembelajaran IPA untuk siswa Sekolah Dasar merupakan awal mula perkenalan anak dengan dunia sains, yaitu dunia makhluk dan benda benda disekitar kita yang mempunyai tujuan dan konsep yang jelas. Adapun tujuan pembelajaran IPA di SD salah satunya yaitu mempersiapkan siswa untuk dapat melakukan penelitian sederhana sehingga siswa mempunyai bekal yang kuat dalam pengembangan ilmu sehari hari. Strategi pengajaran dan pembelajaran strategi pengajaran dan pembelajaran the numbered heads diciptakan oleh Spencer Kagan (1992). Strategi ini menawarkan kesempatan kepada siswa untuk berbagi pemikiran dan memikirkan jawaban yang paling tepat. Selain itu, prosedur ini juga mendorong siswa untuk mengembangkan jiwa kolaborasi mereka. Metode ini dapat digunakan untuk semua mata pelajaran dan untuk semua periode siswa.

Penelitian yang telah dilakukan N. M. Juliartini (2017) pada siswa kelas III Sekolah Dasar No. 2 Abianbase tahun Pelajaran 2016/2017 yang juga menggunakan model pembelajaran NHT menjelaskan bahwa NHT adalah merupakan strategi pembelajaran yang dapat menimbulkan rasa tanggung jawab terhadap siswa dalam mengerjakan tugastugasnya samapai selesai serta melatih perkembangan otak anak untuk mencari tahu sendiri apa yang telah ditugaskan. Salah satu teknik pembelajaran yang menyenangkan yang diterapkan secara luas di sekolah adalah Numbered Head Together atau disingkat sebagai NHT, NHT adalah model pembelajaran yang menekankan pada latihan siswa dalam menemukan, menyiapkan, dan merinci data dari berbagai sumber yang akhirnya diperkenalkan di depan kelas. NHT pertama kali dipresentasikan oleh Spencer Kagan et al (1993). Model NHT penting untuk model pembelajaran yang menyenangkan, yang menonjolkan konstruksi luar biasa yang dimaksudkan untuk mempengaruhi desain asosiasi siswa.

Struktur Kagan mengharapkan siswa untuk bekerja dalam pertemuan-pertemuan kecil yang terpercaya dengan baik. Desain dibuat sebagai bahan elektif untuk konstruksi wali kelas konvensional, misalnya mengangkat tangan terlebih dahulu dan kemudian diberi nama oleh pendidik untuk menjawab pertanyaan yang diajukan. Iklim seperti ini menyebabkan keributan di ruang belajar karena siswa berebut mendapatkan kesempatan untuk menjawab pertanyaan spesialis (Tryana, 2008: 132). Pembelajaran bermanfaat merupakan teknik pembelajaran yang menitikberatkan pada upaya bersama antar siswa dalam pertemuan untuk mencapai tujuan pembelajaran (Suwarto, 2017). Para siswa dipisahkan menjadi pertemuan-pertemuan kecil dan dikoordinasikan untuk membahas topik yang telah diselesaikan. Alasan untuk membentuk pertemuan yang menyenangkan adalah untuk memberikan kebebasan kepada siswa untuk secara efektif dikaitkan dengan siklus penalaran dan dalam latihan pembelajaran. Untuk situasi ini mayoritas latihan pembelajaran difokuskan pada siswa, khususnya perenungan topik dan pemeriksaan untuk memecahkan suatu permasalahan.

Hasil perbaikan pembelajaran yang telah dilaksanakan oleh yang menggunakan model pembelajaran NHT dapat ditarik kesimpulan penerapan metode pembelajaran kooperatif tipe NHT di kelas dapat meningkatkan hasil belajar IPA. Model pembelajaran kooperatif tipe NHT, merupakan salah satu strategi pembelajaran dari jenis jenis strategi model pembelajaran kooperatif. Peakaian model NHT ini dikarenakan pada startegi model 
pembelajaran ini siswa menduduki tempat yang dominan dalam proses kegiatan belajar sehingga terjadi kerja sama dalam kelompok dengan ciri utamanya adanya penomoran sehingga semua siswa berusaha untuk memahami setiap materi yang diajarkan dan bertanggung jawab atas nomor anggotanya masing-masing.

Kurniasih \& Sani, (2015) mejelaskan bahwa pembelajaran kooperatif tipe NHT ini memfokuskan pada komponen khusus yang telang disusun secara sistematis untuk mempengaruhi pola hubungan siswa supaya peserta didikan dapat menguasai dan mencapai tujuan untuk meningkatkan penguasaan akademik. Pembelajaran kooperatif jenis NHT adalah jenis pembelajaran yang menyenangkan yang menggarisbawahi konstruksi luar biasa yang dimaksudkan untuk memengaruhi desain kerja sama siswa dan memiliki tujuan untuk memperluas dominasi akademis. Pembelajaran jenis ini diciptakan oleh Kagen dalam Ibrahim (2000: 28) dengan mengikutsertakan siswa dalam mempertimbangkan materi yang dipelajari dalam sebuah latihan dan memeriksa pemahaman mereka tentang substansi latihan tersebut. Ibrahim mengungkapkan tiga tujuan yang harus dicapai dalam pembelajaran yang menyenangkan dengan tipe NHT, yang secara khusus mendasari hasil pembelajaran ilmiah: berharap untuk meningkatkan pelaksanaan siswa dalam usaha skolastik; Pengakuan tentang variasi: intinya adalah bahwa siswa dapat menghargai teman yang memiliki dasar berbeda; peningkatan kemampuan sosial: berarti untuk mengembangkan kemampuan sosial siswa; kemampuan yang dirujuk untuk menggabungkan tugas berbagi, mengajukan pertanyaan secara efektif, mengenai kesimpulan orang lain, perlu mengklarifikasi pikiran atau sentimen, bekerja dalam pertemuan, dan sebagainya. Pemanfaatan pembelajaran yang menyenangkan jenis NHT mengacu pada gagasan Kagen dalam Ibrahim (2000: 29), dengan tiga tahap khususnya yaitu dibentuknya kelompok, pembicaraan masalah; tukar jawaban antar kelompok.

Sarana tersebut kemudian dikembangkan oleh Ibrahim (2000: 29) menjadi enam tahapan sebagai berikut: Tahap 1 penataan pada tahap ini pendidik menyusun rencana latihan dengan membuat rencana pembelajaran, lembar kerja siswa sesuai model pembelajaran yang bermanfaat yaitu NHT. Tahap 2 pengaturan pertemuan dalam pengembangan pertemuan disesuaikan dengan jenis model pembelajaran NHT yang sesuai. Pengajar membagi siswa menjadi kelompok 3-5 siswa. Pengajar memberikan nomor kepada setiap siswa dalam pertemuan tersebut dan nama kelompok alternatif.Penomoran menjadi perhatian utama di NHT, pada tahap ini pengajar membagi siswa menjadi kelompok atau kelompok yang terdiri dari tiga sampai lima orang dan memberikan nomor kepada siswa sehingga setiap siswa dalam kelompok memiliki nomor yang berbeda, sesuai dengan jumlah siswa dalam kelompok tersebut.Silaturahmi yang dibingkai merupakan perpaduan antara landasan bersahabat, ras, identitas, orientasi seksual dan kapasitas belajar, terlebih lagi dalam membingkai pertemuan nilai pre-test digunakan sebagai alasan untuk menentukan setiap pertemuan. Tahap 3 setiap pertemuan harus memiliki buku kursus atau manual, dalam membingkai pertemuan, setiap pertemuan harus memiliki buku kursus atau manual untuk memudahkan siswa dalam menyelesaikan lembar kerja atau masalah yang diberikan oleh instruktur. Tahap 4 pembicaraan masalah dalam kerja kelompok, pendidik menyerahkan lembar kerja kepada setiap siswa sebagai bahan untuk diperiksa, dalam pekerjaan berkelompok setiap siswa berpikir bersama untuk menggambarkan dan menjamin bahwa semua orang mengetahui tanggapan atas pertanyaan yang ada di lembar kerja atau pertanyaan yang telah diberikan oleh pendidik. Pertanyaan dapat berubah, dari eksplisit menjadi umum. Tahap 5 memanggil nomor part atau menawarkan respon, pada tahap ini instruktur mempertimbangkan satu nomor dan siswa dari setiap pertemuan dengan 
nomor yang sama angkat tangan dan siapkan tanggapan kepada siswa di kelas. Tahap 6 . Memberi berakhir Pendidik dan siswa menutup tanggapan terakhir untuk semua pertanyaan yang diidentifikasi dengan materi yang diperkenalkan.

Ada beberapa keuntungan model pembelajaran yang menyenangkan tipe NHT untuk siswa dengan hasil belajar rendah yang dikemukakan oleh Lundgren dalam Ibrahim (2000: 18), termasuk: penghargaan diri yang lebih tinggi; meningkatkan partisipasi; pengakuan individu menjadi lebih penting; perilaku bermasalah menurun; perjuangan antar manusia berkurang; pengaturan lebih lanjut; peningkatan kebajikan, pengaruh dan resistensi; dengan melihat tanda baca saja, anda dapat berpikir tentang apa saja manfaat model ini, seperti yang dijelaskan oleh Slope ( 1993) dalam Tryana (2008: 132) bahwa model NHT menikmati manfaat termasuk meningkatkan prestasi belajar siswa, memiliki pilihan untuk memperluas pemahaman siswa, memuaskan siswa dalam mengambil, menciptakan perspektif siswa yang positif, menciptakan mentalitas otoritas siswa, menciptakan minat siswa, mengembangkan keberanian siswa, menumbuhkan rasa memiliki tempat, dan menciptakan kemampuan untuk apa yang akan datang.Prestasi berasal dari bahasa Belanda, yaitu "prestatie", dalam bahasa Indonesia prestasi yang mengandung arti akibat dari suatu pengerahan tenaga. Menurut Arifin (2009:12) Prestasi belajar adalah masalah yang mungkin terjadi di seluruh keberadaan manusia, dengan alasan bahwa selama harapan hidupnya orang secara konsisten mencari pencapaian sesuai bidang dan kapasitas masingmasing. Prestasi ini hanya dibatasi dalam dunia pendidikan khususnya dalam pelajaran bahasa Jawa, untuk mengetahui sejuh mana kegiatan pembelajaran berhasil dilaksanakan, maka harus diadakan suatu evaluasi tersebut akan menghasilkan nilai-nilai yang sering dikenal dengan istilah 'prestasi belajar'.

Prestasi belajar adalah hasil dari suatu tindakan yang dibawakan melalui instruksi atau persiapan yang efisien dan teratur sehingga terjadi penyesuaian tingkah laku dan karakter terhadap atasan atau apa yang akan dicapai dalam pembelajaran atau latihan tersebut, dapat dikatakan pula bahwa prestasi belajar merupakan produk dari belajar itu sendiri atau merupakan hasil dari proses belajar. Kehadiran prestasi belajar dalam eksistensi manusia pada level dan tipe tertentu dapat memberikan pemenuhan tertentu bagi manusia. Bagi individu yang masih bersekolah, mereka benar-benar mengharapkan konsep yang luar biasa seperti pencapaian. Sesuai dengan Arifin (2009: 12) prestasi belajar merupakan penanda kualitas dan jumlah informasi yang didominasi oleh siswa; prestasi belajar sebagai gambaran pemenuhan minat, hal ini didasarkan atas asumsi bahwa para ahli spikolog mereka menyebutnya hal ini sebagai tendensi keingintahuan dan merupakan suatu kebutuhan umum pada manusia, termasuk kebutuhan anak didik dalam suatu program pendidikan; prestasi belajar sebagai bahan informasi dan inovasi pendidikan.

Prestasi belajar dapat diasumsikan dan apat dimanfaatkan sebagai kekuatan bagi peserta didik untuk meningkatkan ilmu pengetahuan dan inovasi serta berperan sebagai kritik dan peningkatan hakikat pelatihan; prestasi belajar sebagai penunjuk dalam dan luar dari organisasi instruktif; penanda interior seperti dalam pelaksanaan pembelajaran dapat dimanfaatkan sebagai penanda tingkat efisiensi suatu lembaga pendidikan, yang berpikiran bahwa rencana pendidikan yang digunakan berkaitan dengan kebutuhan masyarakat dan pelajar.Prestasi belajar dapatdimanfaatkan sebagai penanda konsumsi (pengetahuan) peserta didik, dalam interaksi pembelajaran siswa merupakan hal yang mendasar dan pertama karena siswa diharapkan memiliki pilihan untuk menyimpan semua materi yang telah disesuaikan dalam rencana pendidikan. Berdasarkan klarifikasi di atas, bahwa mengetahui dan memahami prestasi siswa, baik secara mandiri maupun berkelompok 
sangatlah penting, mengingat kemampuan prestasi belajar bukan hanya sebagai penanda prestasi di bidang studi tertentu, tetapi juga sebagai tambahan dan juga sebagai penunjuk sifat dasar instruktif. Prestasi belajar juga bermanfaat sebagai masukan bagi instruktur dalam melakukan siklus pembelajaran.

Menurut Cronbach dalam Arifin (2009: 13) manfaat dari prestasi belajar banyak macamnya, tergantung kepada ahli dan pencapaiannya masing masing, salah satu diantaranya adalah:sebagai masukan bagi pengajar dalam mendidik; untuk tujuan analitik; untuk motivasi di balik arahan dan bimbingan; untuk tujuan pilihan; Untuk alasan pengaturan atau jurusan; untuk memutuskan konten program pendidikan; Untuk memutuskan strategi sekolah, dalam Kamus Bahasa Indonesia prestasi belajar mempunyai arti sesuatu yang diandalkan (dibuat, dijadikan dan sebagainya) oleh usaha, yang utama dari prestasi belajar adalah pola tingkah laku yang bulat. Prestasi belajar ditandai dengan perubahan seluruh aspek motorik, aspek kognitif sikap kebiasaan, ketrampilan, maupun pengetahuan, ditandai dengan hafalnya seseorang kepada sesuatu materi yang dipelajari dengan dimanifestikan dalam bentuk-bentuk (1) informasi, (2) definisi, (3) kecenderungan, (4) kemampuan (skill), (5) penghargaan, (6) semangat, (7) hubungan sosial, (8) fisik, (9) moral atau karakter, (10) disposisi.

Sebagaimana ditunjukkan oleh Moh Surya dan Nana Syaodih Sukmadinata dalam Arifin (2009: 14) menyatakan bahwa terlepas dari pandangan-pandangan yang dibicarakan di atas, terdapat juga perubahan sudut pandang: Persepsi, persepsi adalah siklus pengakuan, penerjemahan dan pengutamaan kepentingan sampai tujuan. itu melewati reseptor; penalaran kooperatif memori adalah siklus intuisi di mana hubungan dibentuk antara pemberi energi dan reaksi, pengekangan adalah kapasitas individu untuk memilih aktivitas yang harus dilakukan dan meninggalkan aktivitas yang berlebihan, untuk mengasosiasikan dengan iklim dan berkaitan dengan interaksi pembelajaran.Faktor-faktor yang mempengaruhi prestasi belajar.Menurut Ahmadi dan Supriyono dalam Arifin (2009: 130131) faktor-faktor yang mempengaruhi prestasi belajar antara lain: komponen sosial yang terdiri dari: iklim keluarga, iklim sekolah, iklim lingkungan setempat, iklim. Komponen sosial, unsur sosial meliputi tradisi, ilmu pengetahuan, inovasi dan pengerjaan. Komponen fisik yang sebenarnya. Komponen fisik yang sebenarnya meliputi: keadaan rumah beserta fasilitasnya.Faktor lingkungan spiritual dan keagamaanFaktor dari dalam (internal), unsur fisiologis yang melekat atau diperoleh setelah lahir, yang menggabungkan komponenkomponen tersebut adalah lima deteksi yang tidak bekerja sesuai harapan, tampak terdapat gurun di tubuh atau pergantian peristiwa yang terfragmentasi, berfungsi sebagai organ tubuh yang menyampaikan masalah-masalah sosial.

Ilmu karakter komponen mental, baik yang alami maupun yang di dapat, terdiri dari: faktor ilmiah, yang menggabungkan elemen yang mungkin, dalam pengetahuan dan kemampuan tertentu, dan kemampuan asli, untuk menjadi pencapaian tertentu. Faktor nonilmiah, khususnya komponen karakter tertentu seperti mentalitas, kecenderungan, minat, kebutuhan, inspirasi, perasaan, dan perubahan diri. Faktor perkembangan fisik dan nonaktual, dari pengertian di atas peneliti menyimpulkan bahwa prestasi belajar merupakan daya serap bagi peserta didik dalam pembelajaran menyerap apa yang mereka perhatikan dari penjelasan guru maka mereka dapat berprestasi dengan nilai maksimal sesuai dengan apa yang dikehendakinya. Perolehan nilai maksimal itu ditandai oleh meningkatnya hasil nilai evaluasi yaitu meningkatkan hasil tes tertulis.

Prestasi belajar yang dicapai oleh seorang individu merupakan konsekuensi dari komunikasi berbagai variabel yang berdampak baik dari dalam (faktor dari dalam) maupun 
dari luar (faktor dari luar).Pemahaman pembelajaran pendidik terhadap gagasan mengajar dan belajar akan mempengaruhi pengaturan dan pelaksanaan proses kegiatan belajar. Pengertian belajar mengajar harus dipahami oleh seorang guru agar kegiatan pembelajaran membuahkan hasil yang memuaskan sehingga akan lahir berbagai bentuk kegiatan yang mungkin dilakukan baik oleh siswa maupun oleh guru dalam melaksanakan pembelajaran.

Adapun rumusan masalah dalam penelitian yang akan dilakukan adalah apakah penerapan pembelajaran model NHT dapat meningkatkan prestasi belajar IPA materi perubahan benda siswa kelas VI SD Negeri Cemani 03 Kecamatan Grogol Kabupaten Sukoharjo semester 1 tahun pelajaran 2019/2020.Mengacu pada perumusan dan latar belakang masalah di atas, maka tujuan penelitian ini adalah untuk meningkatkan prestasi belajar IPA materi perubahan benda siswa kelas VI SD Negeri Cemani 03 Kecamatan Grogol Kabupaten Sukoharjo semester 1 tahun pelajaran 2019/2020 melalui model NHT.

\section{Metode Penelitian}

Tempat lokasi penelitian ini akan dilakukan di SD Negeri Cemani 03 Kecamatan Grogol Kabupaten Sukoharjo pada siswa kelas VI semester 1 tahun pelajaran 2019/2020, sesuai dengan tempat tugas peneliti. Mata pelajaran yang akan dilakukan perbaikan adalah mapel IPA materi perubahan benda. Jadwal penelitian ditetapkan selama 5 bulan yaitu dari bulan Agustus 2019 sampai Desember 2019. Peneliti pada pelaksanaan penelitian bermaksud melakukannya dalam 2 (dua) siklus. Setiap siklus akan diadakan tindakan sebanyak 2 kali pembelajaran. Rencana pembelajaran yang telah tersusun dalam jadwal pelaksanaan setiap siklusnya, siklus Iakan dilaksanakan sebnayak dua kali pertemuan, pertemuan 1 dilaksanakan pada hari Rabu, 16 September 2019, pertemuan 2 dilaksanakan pada hari, Rabu, 23 September 2019 dan Jadwal pelaksanaan Siklus II dengan pola yang masih sama dengan siklus I, yaitu sebanyak dua kali pertemuan, akan dijadwalkan pertemuan 1 dilaksanakan pada hari Jumat, 24 Oktober 2019 sedangkan pertemuan 2 dilaksanakan pada hari Jumat, 31 Oktober 2019.Pada penelitian tindakan kelas ini yang akan dijadikan subyek adalah anak didik dari peneliti, yaitu pada peserta didik kelas kelas VI SD Negeri Cemani 03 Sukoharjo semester 1 di tahun pelajaran 2019/2020 dengan jumlah 29 siswa. Penelitian Tindakan Kelas ini akan menggunakan dua buah sumber data, yaitu data primer dan sekunder, data primer diperolehmelalui observasi selama proses tindakan, dengan mengumpulkan data-data peserta didik kelas VI SD Negeri Cemani 03Sukoharjo, tahun pelajaran 2019/2020, setelah peneliti mengumpulkan data primer dari sumber pertama yaitu data siswa kelas VI SD Negeri Cemani 03 Sukoharjo, maka pengumpulan data sekunder dilakukan dengan mengumpulkan data yang di dapat ketika dilakukannya penelitian. Data tersebut dikumpulkan, diolah dan disajikan berupa dokumentasi foto, hasil tes yang telah dilakukan.

Teknik dalam penelitian ini menggunakan teknik observasi atau cara pengamatan langsung, untuk memperoleh data hasil observasi, maka pengamatan dilakukan terhadap siswa kelas VI SD Negeri Cemani 03 Sukoharjo secara langsung. Data yang di dapat dari pengamatan ini berupa respon siswa terhadap proses pembelajaran yang telah diperolehnya, interaksi peserta didik di dalam mengikuti proses kegiatan pembelajaran apakah peserta didik tersebut tertarik dengan model pembelajarn yang diberikan atau tidak, dan hubungan antara rencana pelaksanaan pembelajaran dengan pelaksanaan kegiatan belajar mengajar. Penelitian ini akan di dokumentasikan oleh peneliti dengan cara adalah mengumpulkan semua dokumen pelaksanaan penelitian mulai dari awal dilaksanakan sampai dengan akhir 
pelaksanaan penelitian untuk mendukung hasil penelitian. Pengumpulan dilakukan denagn cara mengamati, melihat dan menuliskan data yang di dapat secara urut dan terperinci. Metode yang akan dipakai adalah metode tes, dimana metode tes ini dapat mengetahui data tentang tingkat keberhasilan setelah pembelajaran berlangsung. Perolehan hasil metode tes akan dijabrakan dalam bentuk kuantitatif. Peneliti akan menggunakan beberapa kali tes untuk mengumpulkan data nilai siswa yang nantinya akan dicari perbandingannya.

Pada penelitian ini akan digunakan teknik triangulasi untuk menguji keabsahan data. Prosedur ini akan memanfaatkan pengamat lainnya dalam hal ini sering kita sebut dengan teman sejawatatau teman satu sekolah yang akan membantu peneliti dalam mengevaluasi.Pada PTK ini menggunakanteknik analisis data kualitatif secara sistematis data yang diperoleh dari hasil pengamatan (observasi), wawancara, catatan lapangan, dan studi dokumentasi, dengan cara mengorganisasikan data ke sintesis, menyusun ke dalam pola, memilih mana yang penting dan mana yang akan dipelajari, dan membuat kesimpulan sehingga mudah difahami oleh diri sendiri maupun orang lain. PTK ini direncanakan terdiri dari dua siklus. Masing masing siklus akan dilakukan dalam dua kali pertemuan. Satu kali pertemuan memerlukan waktu 2 jam pelajaran, jadi satu siklus akan memakan waktu 4 jam pelajaran untuk menyelesaikan kegiatan. PTK yang akan dilakukan memiliki empat tahapan kegiatan yaitu perencanaan, pelaksanaan, observasi dan evaluasi.

Kegiatan yang dilakukan peneliti pada tahap perencanaan tindakan ini adalah menyusun RPPsesuai dengan Kurikulum yang digunakan saat ini, Membuat rencana pelaksanaan pembelajaran dengan menggunakan model pembelajaran NHT. Pelaksanaan pada tahap pelaksaan ini siswa diberikan perlakukan sesuai dengan perencanaan yang telah dibuat. Oservasi atau pengamatan pada tahap ini terdiri dari pengumpulan data serta mencatat setiap aktivitas siswa saat pelaksanaan tindakan yang dilakukan oleh guru selama proses pembelajaran berlangsung dengan mengacu pada lembar observasi yang disediakan. Refleksi merupakan langkah untuk menganalisis semua proses yang terjadi di siklus I yang nantinya akan menjadi bahan perencanaan di siklus selanjutnya. Pada tahap ini peneliti melakukan analisis terhadap proses pelaksanaan pembelajaran siklus I dan hasil belajar berupa nilai siswa pada siklus I, untuk mengetahui kelebihan serta kekurangan maka dilakukan analisid dengan memperhatikan aspek-aspek yang diamati pada siklus I, kemudian peneliti merefleksikan hasil analisis tersebut untuk perbaikan pelaksanaan tindakan pada siklus II. Model pembelajaran tipe NHT dikatakan mampu meningkatkan prestasi belajar IPA pada materi perubahan benda indikator keberhasilan pembelajaran tercapai. Indikator pencapaian penelitian pembelajaran tipe NHT meliputi: prestasi belajar siswa, perolehan prestasi belajar siswa dikatakan berhasil apabila persentase tuntas belajar secara klasikal $\geq 80 \%$ (minimal $80 \%$ siswa memperoleh $\geq 70)$ dan nilai rata-rata kelas $\geq$ 70.

\section{Hasil Penelitian}

Melihat hasil pengamatan yang telah direfleksikan di setiap siklusnya dapat dikatakan bahwa model pembelajaranNHTdapat meningkatkan prestasi belajar IPA pada materi perubahan benda. Hal-Hal tersebut dapat kita lihat pada hasil observasi yang telah direfleksikan pada tiap-tiap siklusnya dapat dilihat dalam tabel berikut.

Tabel 1. Pencapaian Ketuntasan Belajar

\begin{tabular}{lcccc} 
Tahapan Siklus & \multicolumn{2}{c}{ Ketuntasan Siswa } & \multicolumn{2}{c}{ Prosentase Ketuntasan } \\
& Tuntas & Belum Tuntas & Tuntas & Belum Tuntas \\
Kondisi Awal & 17 & 12 & $59 \%$ & $41 \%$ \\
Siklus I & 22 & 7 & $76 \%$ & $24 \%$ \\
\hline
\end{tabular}




\begin{tabular}{lllll}
\hline Siklus II & 29 & 0 & $100 \%$ & $0 \%$ \\
\hline
\end{tabular}

Dari tabel pencapaian ketuntasan di atas diketahui nilai rata-rata prestasi belajar IPA pada kondisi awal adalah 6 , siswa yang memenuhi ketuntasan belajar hanya 17 orang siswa dari 29 orang siswa atau $59 \%$ siswa yang mememnuhi ketuntasan belajar, siswa yang tidak mmemenuhi kriteria ketuntasan sebanyak 12 orang siswa atau $41 \%$ siswa tidak memenuhi kriteria ketuntasan belajar. Sebelum diberikannya tindakan, guru belum menggunakan pembelajaran tipe NHT sehingga proses pembelajaran siswa belum berhasil. Pada siklus I diperoleh data hasil pengamatan Nilai rata-rata prestasi belajar IPA pada siklus I adalah 74 . Siswa yang memenuhi kriteria ketuntasan belajar sebanyak 22 orang siswa dari 29 orang siswa atau $76 \%$ siswa yang memenuhi kriteria ketuntasan belajar. Siswa yang belum memenuhi kriteria ketuntasan sebanyak 7 orang siswa atau 24\%. Guru telah menggunakan model pembelajaran tipe NHT proses pembelajaran siswa sudah cukup berhasil, tetapi hasilnya belum maksimal sehingga guru memutuskan untuk melanjutkan ke siklus selanjutnya. Pada siklus ke II ini diperoleh nilai rata-rata $100 \%$ siswa telah mampu memenuhi bahkan telah melampaui ketuntasan belajar, siswa yang tidak mencapai ketuntasan sebanyak 0 siswa atau $0 \%$. Perolehan data hasil belajar IPA materi perubahan benda dari kondisi awal sampai siklus II, dengan menerapkan model pembelajaran NHT dapat dilihat pada tabel di bawah ini:

\begin{tabular}{llccc}
\multicolumn{4}{c}{ Tabel 2. Peningkatan Hasil Belajar } \\
\hline No & Uraian & Kondisi Awal & Siklus I & Siklus II \\
1 & Nilai Tertinggi & 80 & 90 & 100 \\
2 & Nilai Terendah & 60 & 60 & 80 \\
3 & Nilai rata-rata & 67 & 74 & 84 \\
4 & Tuntas & 17 & 22 & 29 \\
5 & Tidak tuntas & 12 & 7 & 0 \\
\hline
\end{tabular}

Sejalan dengan penelitian yang telah dilakukan oleh Devi Ayu Ertanti (2016) berjudul Penerapan Model Pembelajaran Kooperatif NHT Pada Mata Pelajaran IPA untuk Meningkatkan Prestasi Belajar Siswa Kelas VI Sekolah Dasar. Hasil penelitian tersebut juga menunjukkan peningkatan prestasi dan aktivitas siswa dalam pembelajaran, dengan demikian hipotesis tindakan penelitian tindakan kelas ini bahwa melalui penerapan model pembelajaran NHT di duga dapat meningkatkan prestasi belajar siswa materi Perubahan benda siswa kelas VI SD Negeri Cemani 03 Kecamatan Grogol Kabupaten Sukoharjo semester 1 tahun pelajaran 2019/2020, terbukti kebenarannya

\section{Pembahasan}

Hipotesis tindakan yang menyatakan bahwa melalui penerapan model pembelajaran NHT di duga dapat meningkatkan prestasi belajar siswa materi perubahan benda siswa kelas VI SD Negeri Cemani 03 Kecamatan Grogol Kabupaten Sukoharjo semester 2 tahun pelajaran 2019/2020terbukti kebenarannya. Hal tersebut terbukti dengan perolehan rata-rata prestasi belajar IPA perubahan benda beserta peningkatan pencapaian tingkat ketuntasan belajar IPAdi setiap siklus tindakan yang telah dilakuikan mulai dari sklus I sampai dengan siklus II. Prestasi belajar IPA perubahan benda pada kondisi awal diketahui masih di bawah kriteria ketuntasan minimal yang diharapkan, dengan perolehan nilai rata rata pada kondisi awal hanyalah 67 . Berdasarkan hasil tersebut, maka siswa kelas VI SD Negeri Cemani 03, Kecamatan Grogol, Kabupaten Sukoharjo, semester 1 tahun 
pelajaran 2019/2020secara klasikal belum mencapai ketuntasan belajar, sehingga diputuskan untuk memberikan tindakan kelas dengan penerapan model pembelajaran NHT. Kegiatan pembelajaran siklus I, setelah diberikannya tindakan kelas diperoleh nilai rata-rata hasil belajar siswa yaitu 74, dari kondisi awal ke siklus I terjadi peningkatan, meskipun belum maksimal, karena dirasa belum maksimal maka peneliti memutuskan untuk melanjutkan pada siklus II dengan memberikan tindakan yang sama seperti siklus I dengan harapan akan mencapai hasil yang optimal pada tindakan pembelajaran Siklus II yaitu diperoleh nilai rata rata sebesar 84 , karena dirasa telah maksimal dan telah mencapai $100 \%$ siswa yang telah mencapai ketuntasan maka peneliti tidak melanjutkan penelitian ke siklus selanjutnya.Penelitianjuga pernah dilakukan oleh Sumardjono (2017) pada siswa kelas IVA SDN Plumbon 01 Tahun Pelajaran 2016/2017 di Semester 2 hasil penelitian tersebut menunjukkan terjadi peningkatan hasil belajar melalui penggunaan model pembelajaran NHT. Hasil penelitian menunjukkan bahwa model pemlajaran NHT terbukti dapat meningkatkan prestasi belajar siswa.

\section{Simpulan dan Saran}

Berdasarkan hasil penelitian tindakan kelas, maka dapat disimpulkan sebagai berikut melaluipenerapan model pembelajaran NHT dapat meningkatkan prestasi belajar siswa kelas VI SDN Cemani 03 Sukoharjo semester I tahun pelajaran 2019/2020, telah terbukti kebenarannya. Berdasarkan data hasi penelitian membuktikan dengan peningkatan prestasi belajar IPA materi perubahan benda, perolehan nilai rata-rata kelas siswa kelas VI, di kondisi awal pra tindakan hanyalah 67, kemudian setelah mendapat tindakan dengan model pembelajaran di siklus I perolehan nilai rata rata kelas mencapai nilai 74 , terjadi peningkatah yang lebih baik dari siklus I dibandingkan dengan kondisi awal pra tibdakan, meskipun telah mencapai rata rata sebesar 74 tetapi dirasa belum maksimal sehingga peneliti memutuskan untuk melanjutkan ke siklus selanjutnya yaitu siklus II, pada siklus II ini terjadi peningkatan yang sangat signifikan dengan perolehan rata rata prestasi belajar IPA perubahan benda mencapai rata rata sebesar 84 pada siklus II.

Peningkatan juga terbukti dari ketuntasan belajar siswa juga mengalami peningkatan belajar dari $69 \%$ pada kondisi awal meningkat menjadi $76 \%$ pada siklus I dan meningkat menjadi $100 \%$ pada siklus II, dilihat dari peningkatan nilai rata-rata ulangan harian dan ketuntasan belajar peningkatan kriteria ketuntasan secara klasikal jugasudah tercapai, yaitu mencapai tingkat ketuntasan kelas sebesar $100 \%$ atau $\leq \mathrm{KKM}$ sebesar $80 \%$. Sehingga diputuskan untuk berhenti dan tidak melanjutkan ke siklus selanjutnya.Saran yang dapat peneliti sampaikan setelah melaksanakan perbaikan pembelajaran yaitu, hendaknyaguru dapat menerapkanmodel model pembelajaran kooperatif lainnya sebagai salah satu solusi pemecahan masalah yang dihadapi dalam proses pembelajaran di dalam kelas, pembelajaran IPA hendaknya menerapkan model-model pembelajaran yang dapat merangsang dan memotivasi siswa lebih variatif, agar siswa tidak bosan dan tertarik untuk mengikuti pelajaran

\section{Daftar Rujukan}

Arifin, Zainal.(2009). Evaluasi Pembelajaran. Bandung : PT Remaja Rosda Karya. Asy'ari, Maslichah.(2006). Penerapan Pendekatan Sains Teknologi Masyarakat dalam Pembelajaran Sains di Sekolah Dasar. Yogyakarta: Universitas Sanata Dharma. 
Desak Ketut Paramita.(2016). Penerapan Model Pembelajaran Kooperatif Tipe NHT Berbantuan Media Audio Visual Untuk Meningkatkan Hasil Belajar IPA. E-Journal PGSD, volume 4(1), hal: 30-40.

Devi Ayu Ertanti. (2016). Penerapan Model Pembelajaran Kooperatif NHT Pada Mata Pelajaran IPA untuk Meningkatkan Prestasi Belajar Siswa Kelas VI Sekolah Dasar. Jurnal PGMI, volume 3(1), hal: 40-50.

Djojosoediro. (2010). Pengembangan dan Pembelajaran IPA SD. Malang: UNM Pers. Kamus Besar Bahasa Indonesia, Edisi Keempat. (2008). Jakarta: Gramedia Pustaka Kurniasih \& Sani. (2015). Model Pembelajaran. Jakarta: Kata Pena. Ibrahim.(2000). Pembelajaran Kooperatif. Surabaya : University Press.

N. M. Juliartini.(2017). Penerapan Model Pembelajaran NHT Untuk Meningkatkan Hasil Belajar IPA Siswa Kelas III. Jurnal of Education Action Research, volume 1(3), hal: $60-70$.

Rabiah. (2018). Peningkatan Hasil Belajar IPA Melalui Penerapan Model Pembelajaran Kooperatif Tipe NHT Di Kelas IV SD Negeri 031 Pulau Kijang. Jurnal Pajar, volume 2(3), hal: 40-50.

Syaodih, Nana.(2010). Metode Penelitian Pendidikan. Bandung: Remaja Rosdakarya Sumardjono. (2017). Penerapan Model Pembelajaran Kooperatif Tipe Numbered Heads Together (NHT) Untuk Meningkatkan Hasil Belajar IPA Kelas IVA Sekolah Dasar. Jurnal PGSD, volume 3(4), hal: 70-80.

Suprapti Hariyani. (2019). Peningkatan Aktivitas dan Hasil Belajar IPA Materi Sistem Ekskresi Manusia melalui Model Pembelajaran Discovery Learning dan Metode Eksperimen Siswa Kelas VIII G SMP Negeri 1 Boyolali pada Semester Genap Tahun Pelajaran 2018-2019. Jurnal Pendidikan, volume 28(3), hal: 339-352.

Susanto, Ahmad.(2014). Teori Belajar \& Pembelajaran di Sekolah Dasar. Jakarta: Prenada Media Group.

Suwarto, S. (2009). Pengembangan tes dan analisis hasil tes yang terintegrasi dalam program komputer. Jurnal Penelitian dan Evaluasi Pendidikan, 13(1), 40-56.

Suwarto, S. (2017). Pengembangan tes ilmu pengetahuan alam terkomputerisasi. Jurnal Penelitian dan Evaluasi Pendidikan, 21(2), 153-161.

Tryana, Antin. (2008). Penerapan Model Pembelajaran Kooperatif Numbered Heads Together (NHT).(http://Alt.Red/clnerwork/numbered.htm), diakses tanggal 12 Juli 2019.

Undang-undang No. 20 Tahun 2003 Tentang Sistem Pendidikan Nasional 